(c) American Dairy Science Association, 2005.

\title{
A Meta-Analysis on the Relationship Between Intake of Nutrients and Body Weight with Milk Volume and Milk Protein Yield in Dairy Cows
}

\author{
A. N. Hristov, ${ }^{1}$ W. J. Price, ${ }^{2}$ and B. Shafii ${ }^{2}$ \\ ${ }^{1}$ Department of Animal and Veterinary Science, and \\ ${ }^{2}$ Statistical Programs, College of Agricultural and Life Sciences, University of Idaho, Moscow 83844
}

\begin{abstract}
Previously observed strong relationships between dry matter (DM) intake and milk yield in dairy cows were the basis for this meta-analysis aimed to determine the influence of intake of specific dietary nutrients on milk yield and milk protein yield in Holstein dairy cows. Diets (563) from feeding trials published in the Journal of Dairy Science were evaluated for nutrient composition using 2 diet evaluation programs. Intake of nutrients was estimated based on DM intake and programderived diet composition. Data were analyzed with and without the effect of stage of lactation. Models based on intake of nutrients improved prediction of milk yield and milk protein yield compared with DM intake alone. Intake of net energy of lactation was the dominant variable in milk yield prediction models derived from both diet evaluation models. Milk protein yield models also improved prediction over the DM intake model. These models were dominated by ruminally undegradable protein intake and included a number of energy-related intake variables. In most models, incorporating stage of lactation improved the model fit.
\end{abstract}

(Key words: dairy cow, nutrient intake, milk yield, milk protein yield)

Abbreviation key: $\mathbf{A C}=$ all cows, $\mathbf{B I C}=$ Bayesian information criterion, $\mathbf{C H O}=$ carbohydrates, $\mathbf{C P M}=$ model based on CPM Dairy, version 1.0, DIM1 = earlylactation cows (DIM < 100), DIM2 = mid- and latelactation cows $(\mathrm{DIM} \geq 100), \mathbf{M Y}=$ milk yield, $\mathbf{M P Y}=$ milk protein yield, NRC = model based on NRC (2001), VIF = variance inflation factor .

\section{INTRODUCTION}

Dry matter intake and milk yield (MY) are fundamentally related in dairy cows. The lag between peak MY and peak DMI in the early stages of lactation ap-

Received November 10, 2004.

Accepted April 6, 2005.

Corresponding author: A. N. Hristov; e-mail: ahristov@uidaho.edu. pears to support the concept that intake is driven by milk production (NRC, 2001). Reports by Moore and Mao (1990), Rook et al. (1992), and Fuentes-Pila et al. (2003) confirmed the strong relationship between DMI and MY in the lactating dairy cow. A survey of a large data set including nutritional studies published in the Journal of Dairy Science (volumes 1 to 82) showed a moderate linear relationship $\left(\mathrm{r}^{2}=0.47\right)$ between DMI and MY (Hristov et al., 2000, 2004). In addition to DMI, intake of dietary energy and protein, or individual carbohydrate (CHO) and protein fractions may be important factors in controlling MY and milk protein yield (MPY) in dairy cows (DePeters and Cant, 1992; Hristov et al., 2004).

Dietary DM is a multicomponent entity. Diet evaluation and formulation models, using various procedures, have separated dietary $\mathrm{CP}$ and energy-yielding substrates into fractions characterized by different rates and extents of ruminal and total tract digestion (Jarrige, 1989; Sniffen et al., 1992; NRC, 2001). The Cornell Net Carbohydrate and Protein System fractionated feed $\mathrm{CHO}$ and proteins through physical or chemical methods (Sniffen et al., 1992); CPM Dairy, a computer program based on the Cornell Net Carbohydrate and Protein System principles, is commonly used in formulating diets for dairy cattle in the United States. In NRC (2001), information on feed protein degradability from in situ fermentation was used and $\mathrm{CHO}$ fractions were separated based on chemical analyses (NDF/ADF) or by difference (NFC). In this context, intakes of individual nutrients, rather than DMI, may be better predictors of MY and MPY in dairy cows.

Thus, the objective of this meta-analysis was to develop prediction models for MY and MPY in Holstein dairy cows based on DMI, intake of dietary nutrients (estimated with 2 diet evaluation models), and BW.

\section{MATERIALS AND METHODS}

\section{Input Data}

Diets (563 treatment means) from feeding trials (173) involving Holstein cows conducted in the United States 
Table 1. Summary statistics for intake variables and responses considered for the CPM and NRC models $(\mathrm{n}=563){ }^{1}$

\begin{tabular}{|c|c|c|c|c|c|}
\hline & Mean & Median & Min & Max & $\mathrm{SD}$ \\
\hline & & - & $r$ as indi & & - \\
\hline \multicolumn{6}{|l|}{ CPM models } \\
\hline $\mathrm{CP}$ & 4.0 & 3.9 & 2.0 & 6.1 & 0.64 \\
\hline RDP & 2.6 & 2.6 & 1.2 & 4.1 & 0.46 \\
\hline RUP & 1.4 & 1.3 & 0.7 & 2.8 & 0.32 \\
\hline Soluble protein & 1.5 & 1.5 & 0.5 & 3.0 & 0.43 \\
\hline $\mathrm{NE}_{\mathrm{L}}, \mathrm{Mcal} / \mathrm{d}$ & 37.9 & 37.6 & 23.7 & 52.9 & 4.72 \\
\hline NDF & 6.8 & 6.7 & 4.2 & 11.4 & 1.23 \\
\hline Nonstructural carbohydrates & 9.4 & 9.3 & 4.6 & 14.1 & 1.64 \\
\hline Fermentable carbohydrate & 9.0 & 9.0 & 6.2 & 12.7 & 1.05 \\
\hline Fermentable NDF & 2.1 & 2.0 & 1.1 & 4.7 & 0.52 \\
\hline Carbohydrate fraction A & 1.1 & 1.1 & 0.3 & 2.7 & 0.34 \\
\hline Protein fraction B1 & 0.46 & 0.47 & 0.03 & 1.01 & 0.179 \\
\hline Protein fraction B2 & 1.9 & 1.9 & 0.8 & 3.1 & 0.43 \\
\hline \multicolumn{6}{|l|}{ NRC } \\
\hline $\mathrm{CP}$ & 3.9 & 3.9 & 1.9 & 6.1 & 0.65 \\
\hline RUP & 1.2 & 1.2 & 0.6 & 2.1 & 0.30 \\
\hline RDP & 2.7 & 2.7 & 1.1 & 4.3 & 0.53 \\
\hline $\mathrm{NE}_{\mathrm{L}}, \mathrm{Mcal} / \mathrm{d}$ & 35.6 & 35.6 & 25.0 & 46.2 & 3.71 \\
\hline NFC & 9.2 & 9.2 & 3.8 & 13.6 & 1.65 \\
\hline $\mathrm{NDF}$ & 6.8 & 6.6 & 3.9 & 11.2 & 1.18 \\
\hline Forage NDF & 4.9 & 4.8 & 1.3 & 9.1 & 1.16 \\
\hline Fat & 0.88 & 0.77 & 0.43 & 1.94 & 0.321 \\
\hline BW (kg) & 601 & 600 & 476 & 750 & 45.7 \\
\hline \multicolumn{6}{|l|}{ Response variables } \\
\hline DMI & 22.2 & 22.0 & 16.0 & 29.9 & 2.57 \\
\hline Milk yield & 32.2 & 32.0 & 20.3 & 47.7 & 5.43 \\
\hline Milk protein yield & 0.99 & 0.99 & 0.62 & 1.57 & 0.156 \\
\hline
\end{tabular}

${ }^{1} \mathrm{CPM}=\mathrm{CPM}$ Dairy, a computer program based on the Cornell Net Carbohydrate and Protein System principles; NRC model is based on NRC (2001).

and Canada published in the Journal of Dairy Science (volumes 73 through 83)* were evaluated for nutrient composition using 2 diet evaluation models: CPM Dairy [version 1.0; Cornell University, Ithaca, NY; University of Pennsylvania, Kennett Square, PA; and William H. Miner Agricultural Research Institute, Chazy, NY; (CPM)] and National Research Council (2001) (NRC). Nutrient intakes were estimated based on published DMI and CPM- or NRC-derived compositions. Feeds (and level of processing) listed in the publications were matched with feeds from feeding model libraries. The chemical composition of dietary energy and proteinaceous concentrates was not edited. Whenever available (in $46.5 \%$ of the studies), $\mathrm{CP}$ and NDF concentration of forages were modified to reflect actual published, dietary concentrations. Although the output from these nutritional programs may not reflect the actual nutrient composition of each diet, it does provide reasonable estimates. Details on feed ingredients and diet composition are given in Hristov et al. (2004) and Table 1.

\footnotetext{
*A complete list of references used in the meta-analysis is available as a data supplement online (http://jds.fass.org).
}

Compared with our previous work (Hristov et al., 2004), the size of the data set used in this analysis was reduced to involve only studies in which BW of the cows was published. The data were analyzed both as a set (all cows; AC), without regard to DIM and as cows grouped into 2 categories according to lactation stage: earlylactation cows (DIM < 100; DIM1) and mid and latelactation cows (DIM $\geq 100$; DIM2). This grouping was based on the assumption that DMI is limiting milk production in the early stages of lactation (wk 12 to 16; Kertz et al., 1991; Roseler et al., 1997b), whereas cows beyond 100 DIM would normally be in positive nutrient (energy) balance.

The response variables were MY and MPY. The average $( \pm \mathrm{SD}) \mathrm{DMI}$ of the cows involved in this study was $22.2 \pm 2.6 \mathrm{~kg} / \mathrm{d}$ with a minimum of 16.0 and a maximum of $29.9 \mathrm{~kg} / \mathrm{d}$. Average MY was $32.2 \pm 5.4 \mathrm{~kg} / \mathrm{d}$ and had a minimum of 20.3 and maximum of $47.7 \mathrm{~kg} / \mathrm{d}$. Average milk fat and milk protein concentrations were $3.5 \pm 0.4$ and $3.1 \pm 0.21 \%$, respectively. Average MPY was 0.99 $\pm 0.16 \mathrm{~kg} / \mathrm{d}$ with a minimum and maximum of 0.62 and $1.57 \mathrm{~kg}$, respectively. Average milk protein N efficiency [(milk protein yield $\div 6.38) \div \mathrm{N}$ intake] was $24.9 \pm 4.2 \%$ with a minimum and maximum of 13.7 and $43.6 \%$, re- 
spectively. Mean BW was $601 \pm 46 \mathrm{~kg}$ (minimum 476, maximum $750 \mathrm{~kg}$ ). The dietary variables derived from the feeding programs and considered in this structural analysis are given in Hristov et al. (2004). Ratios among protein and energy variables and BW were considered for having potential relationships with the response variables. In this analysis, not all variables were present across all observations in the data set. Hence, the number of observations used for regression analyses varied between MY and MPY models depending on the regressor variables available.

\section{Statistical Analyses}

Details on variable selection and statistical analysis were similar to Hristov et al. (2004). As an initial step, the data were inspected for similarity among the nutritional variables. Because most of the data were derived from computational nutritional programs, some variables were essentially numeric derivatives of others, and thus, would be redundant as regressors in any subsequent analysis. This situation could be quickly assessed by calculating simple linear correlations among the nutritional variables. Pairs of explanatory variables having correlation values larger than 0.80 were considered to indicate sufficient redundancy to warrant action. In most cases, only one variable of the pair was selected for further analysis. Preference in these cases was given based on the biological relevance or the reliability of the analytical procedures used to derive the variables (NDF vs. effective NDF, for example).

Multiple linear regression was then used to investigate the structural relationship among the responses, MY and MPY, and DMI and the remaining nutrient intakes obtained from CPM and NRC programs. Because the data used in this meta-analysis were collected from multiple studies conducted over many years, the random effects of each study needed to be accounted for in the modeling process (St-Pierre, 2001). In this case, random effects were incorporated into the estimation procedure using a mixed model framework. The general form of the mixed model is as follows:

$$
\mathbf{Y}=\mathbf{X} \beta+\mathbf{Z} \gamma+\varepsilon,
$$

where $\mathrm{Y}$ is the response being modeled, $\mathrm{X}$ is a matrix of the intercept term and the nutritional variables, and $\beta$ is a vector of the corresponding regression coefficients. These terms represent the fixed portion of the model and are equivalent to those found in a standard multiple linear regression. The additional components, $\mathrm{Z}$ and $\gamma$, account for the random effects due to the various studies; $\mathrm{Z}$ represents either all or a portion of the variables present in $\mathbf{X}$, and $\gamma$ is a vector of their associated coefficients; $\varepsilon$ is a random error term and is assumed to be normally distributed with a mean of 0 and constant variance.

To account for the precision of each study, each regression analysis was weighted by the reciprocal of the squared response standard errors, as reported in each study (St-Pierre, 2001).

Because some intake regressors still exhibited collinearity, subsets of regressors were created within each of the CPM and NRC datasets. In each case, the subsets were chosen such that any highly correlated variables were separated, i.e., they did not occur within the same subsets, and the variance inflation factor (VIF), a statistic measuring collinearity, for the subset was less than 30. To identify a final model from each subset, the backwards elimination technique described by Oldick et al. (1999) and Firkins et al. (2001), was used for variable selection. At each stage of elimination, the $P$ value and VIF of each variable were evaluated as described in Oldick et al. (1999). Once the selection process had identified a reduced model, all possible 2 -way interactions and quadratic terms derived from the remaining variables were added to the model. The backwards elimination procedure was then repeated, except that main effects remained in the model, even when nonsignificant, if they were involved in any significant interaction or squared term.

Estimation for all models was carried out using the method of restricted maximum likelihood assuming a diagonal variance-covariance (variance component) structure among the regressors. A final model for each response was selected from the subset candidates based on the lowest value of the Bayesian information criteria (BIC), the smallest final set of regressors (model parsimony), parameter significance, residual analysis, and biological relevance. In addition, mean and linear bias of the selected models was assessed following St-Pierre (2003). All statistical computations were carried out using the PROC MIXED, PROC REG, PROC CORR, and PROC GPLOT procedures of the SAS software system (SAS Institute, 2004).

\section{RESULTS}

Diets included in the study contained corn silage, alfalfa silage, and hay as predominant forages, corn and barley grains as main energy concentrates, and solvent-extracted soybean meal as the main protein supplement. The diets represented a wide range of $\mathrm{CP}$ and RDP concentrations; respectively, the intake of these nutrients varied significantly among diets (Table 1). Diet evaluation models differed slightly in derivation of common variables such as $\mathrm{CP}, \mathrm{NDF}, \mathrm{RUP}$, and RDP. 
Table 2. Significant $(P<0.05)$ simple correlations among intake variables and responses considered in the CPM model $(\mathrm{n}=557) .{ }^{1}$

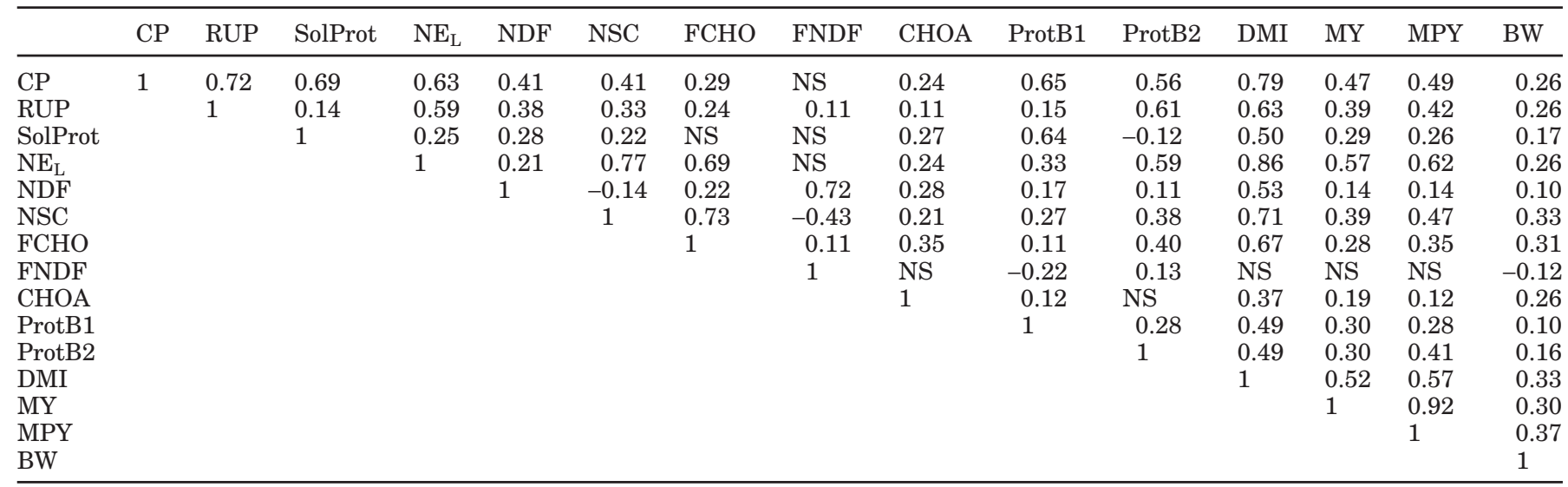

${ }^{1}$ Intake and production data are in kilograms per day (megacalories per day for $\mathrm{NE}_{\mathrm{L}}$ ). SolProt = Soluble protein; NSC = nonstructural carbohydrates; FCHO = fermentable carbohydrates; FNDF = fermentable NDF; CHOA = carbohydrate fraction A; ProtB1 = protein fraction $\mathrm{B} 1 ;$ ProtB2 $=$ protein fraction $\mathrm{B} 2 ; \mathrm{MY}=$ milk yield; $\mathrm{MPY}=$ milk protein yield .

NS = Nonsignificant $(P>0.05)$.

A larger difference was observed for $\mathrm{NE}_{\mathrm{L}}$ likely due to the different approach in estimating energy content of feeds in NRC (NRC, 2001).

Correlation matrices for the 2 datasets are shown in Tables 2 and 3. Milk yield correlated (Pearson correlation) positively $(P<0.001)$ to $\mathrm{DMI}$ and intake of $\mathrm{NE}_{\mathrm{L}}$, $\mathrm{CP}, \mathrm{RUP}$, and nonstructural carbohydrates in the CPM data set. Correlation to CPM-derived fermentable carbohydrate (CHO) and carbohydrate fraction A and protein fractions B1 and B2 was relatively weaker or nonsignificant (fermentable NDF). The correlation between MPY, DMI, and other intake variables paralleled those for MY. For the NRC data set, MY was highly correlated to $\mathrm{NE}_{\mathrm{L}}, \mathrm{DMI}$, fat, and protein fractions intakes. Milk protein yield was correlated to $\mathrm{NE}_{\mathrm{L}}, \mathrm{DMI}, \mathrm{CP}$, and $\mathrm{NFC}$ intakes. With the exception of RDP and CP in the NRC data set, correlations among regressor variables were below 0.80 for both datasets.

\section{Modeling}

For each response, the backwards selection procedure was used to identify a model, which had acceptable residual structure, VIF, BIC, and model parsimony, as outlined above. All final models showed good prediction with residuals that had no discernible trend or pattern. All model residuals were tested for significant mean and linear biases. In all cases, the biases were either nonsignificant or small relative to the measured standard errors based on analyses similar to St-Pierre (2003). Residual plots for the models with the lowest

Table 3. Significant $(P<0.05)$ simple correlations among intake variables and responses considered in the NRC model $(\mathrm{n}=557){ }^{1}$

\begin{tabular}{lllllllllllll}
\hline & CP & RUP & RDP & NE $_{\mathrm{L}}$ & NDF & ForNDF & NFC & Fat & DMI & MY & MPY & BW \\
\hline CP & 1 & 0.60 & 0.88 & 0.74 & 0.45 & 0.24 & 0.38 & 0.18 & 0.79 & 0.47 & 0.49 & 0.25 \\
RUP & & 1 & 0.18 & 0.61 & 0.25 & NS & 0.30 & 0.31 & 0.53 & 0.37 & 0.42 & 0.18 \\
RDP & & & 1 & 0.57 & 0.41 & 0.30 & 0.28 & NS & 0.67 & 0.37 & 0.37 & 0.21 \\
NE $_{L}$ & & & & 1 & 0.40 & NS & 0.68 & 0.53 & 0.92 & 0.59 & 0.63 & 0.25 \\
NDF & & & & & 1 & 0.59 & -0.10 & 0.15 & 0.56 & 0.16 & 0.16 & 0.11 \\
ForNDF & & & & & & 1 & -0.13 & -0.13 & 0.27 & NS & NS & NS \\
NFC & & & & & & & 1 & NS & 0.70 & 0.36 & 0.45 & 0.35 \\
Fat & & & & & & & & 1 & 0.26 & 0.41 & 0.36 & NS \\
DMI & & & & & & & & & 1 & 0.52 & 0.57 & 0.33 \\
MY & & & & & & & & & & 1 & 0.92 & 0.30 \\
MPY & & & & & & & & & & & 1 & 0.36 \\
BW & & & & & & & & & & & & \\
\hline
\end{tabular}

${ }^{1}$ Intake and production data are in kilograms per day (megacalories per day for $\mathrm{NE}_{\mathrm{L}}$ ). ForNDF = forage $\mathrm{NDF} ; \mathrm{Fat}=$ dietary fat $\mathrm{MY}=$ milk yield $; \mathrm{MPY}=$ milk protein yield .

NS = Nonsignificant $(P>0.05)$. 
A

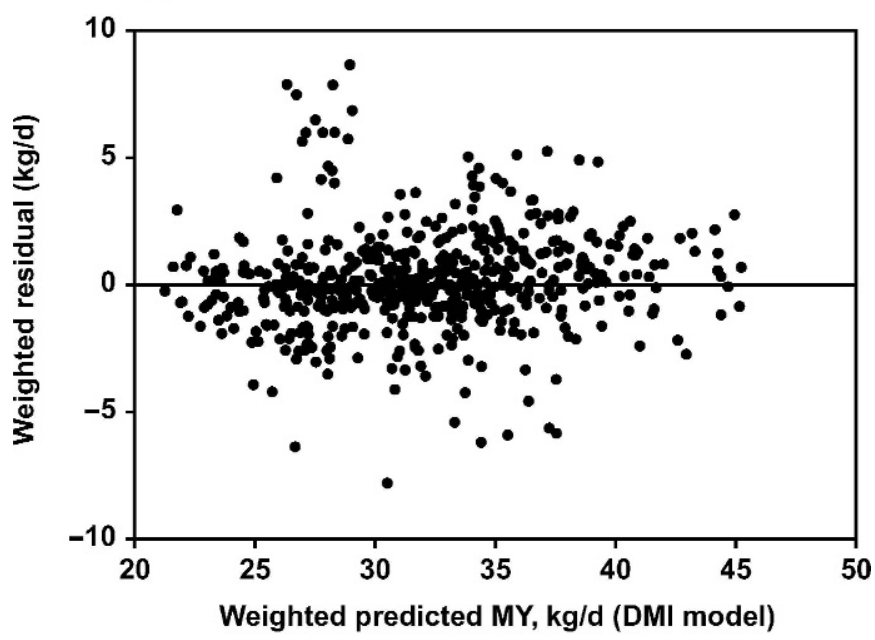

B

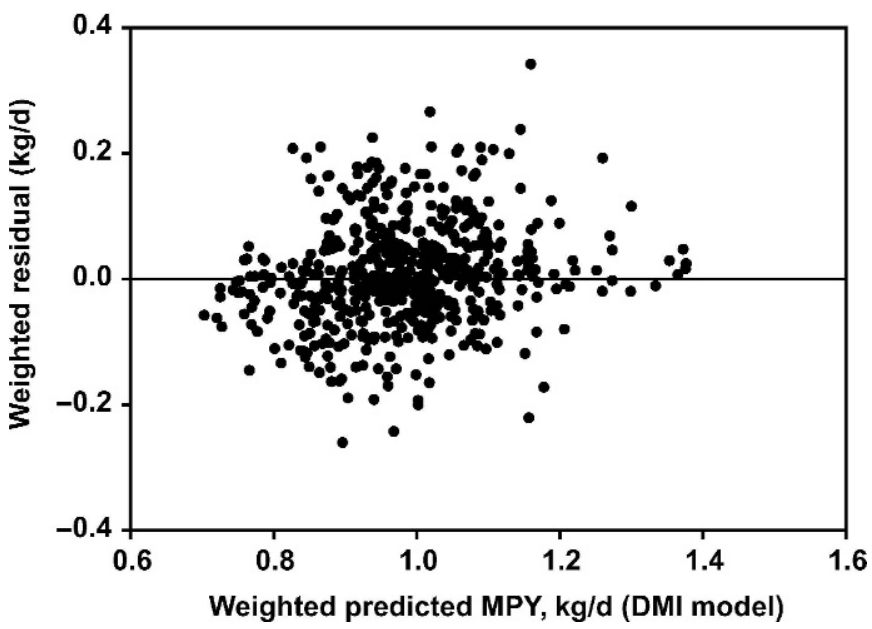

Figure 1. Weighted residuals (weighted observed - weighted predicted) vs. weighted predicted milk yield (MY) and milk protein yield (MPY). A) MY, DMI model (model 1); B) MPY, DMI model (model 6).

BIC value (AC or DIM models) are shown in Figures 1,2 , and 3 .

\section{Milk Yield Models}

Estimated MY models are shown in Table 4. Net energy of lactation intake and fermentable $\mathrm{CHO}$ and protein fraction $\mathrm{B} 2$ intakes were significant factors in the CPM-AC and CPM-DIM models (models 2 and 3). Intake of fermentable $\mathrm{CHO}$ had a negative influence in the model. Incorporation of CPM-derived intake variables instead of DMI (model 1) substantially improved model fit as measured by the 29- to 138-unit decrease in BIC and improved overall residual structure (Figure 1A). Incorporation of DIM into the CPM model (model 3) improved model fit as measured by the 109-unit de-
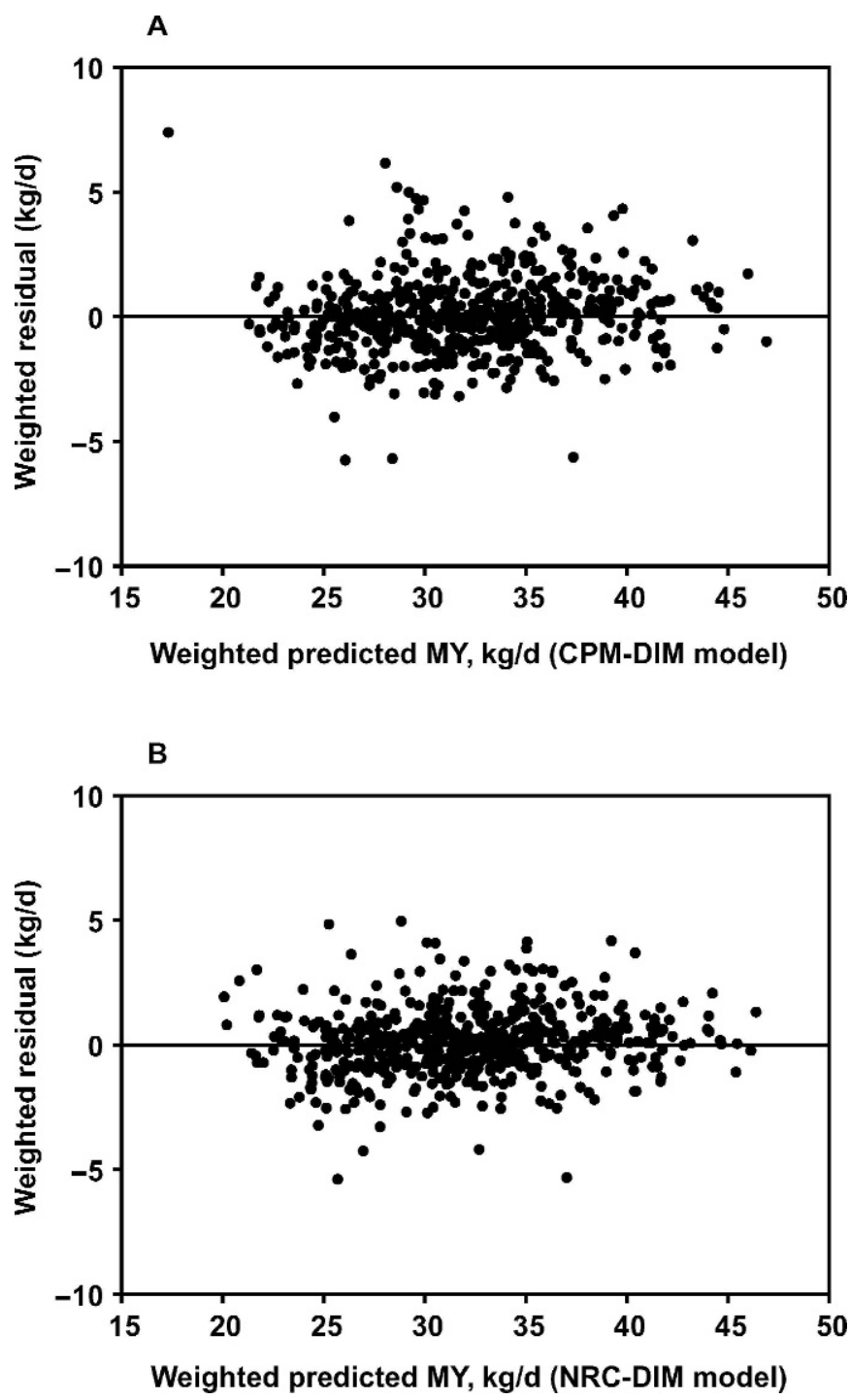

Figure 2. Weighted residuals (weighted observed - weighted predicted) vs. weighted predicted milk yield (MY). A) CPM-DIM model (model 3); B) NRC-DIM model (model 5). CPM = CPM Dairy, a computer program based on the Cornell Net Carbohydrate and Protein System principles; NRC $=$ model based on NRC (2001).

crease in BIC as well as an improved relationship between observed and predicted values and overall residual structure (Figure 2A). Intake of protein fraction B2 showed significantly different coefficients for DIM1 and DIM2 classes. In both the full and reduced models, protein fraction B2 had significant interactions with the random effects of study.

The NRC models (models 4 and 5) included $\mathrm{NE}_{\mathrm{L}}$ supply, RUP intake, and BW as explanatory variables. The models also contained an interaction between RUP intake and BW. Similar to the CPM models, incorporation of NRC-derived intake variables instead of DMI (model 1) improved the model fits, as BIC was 56 and 212 units 
A
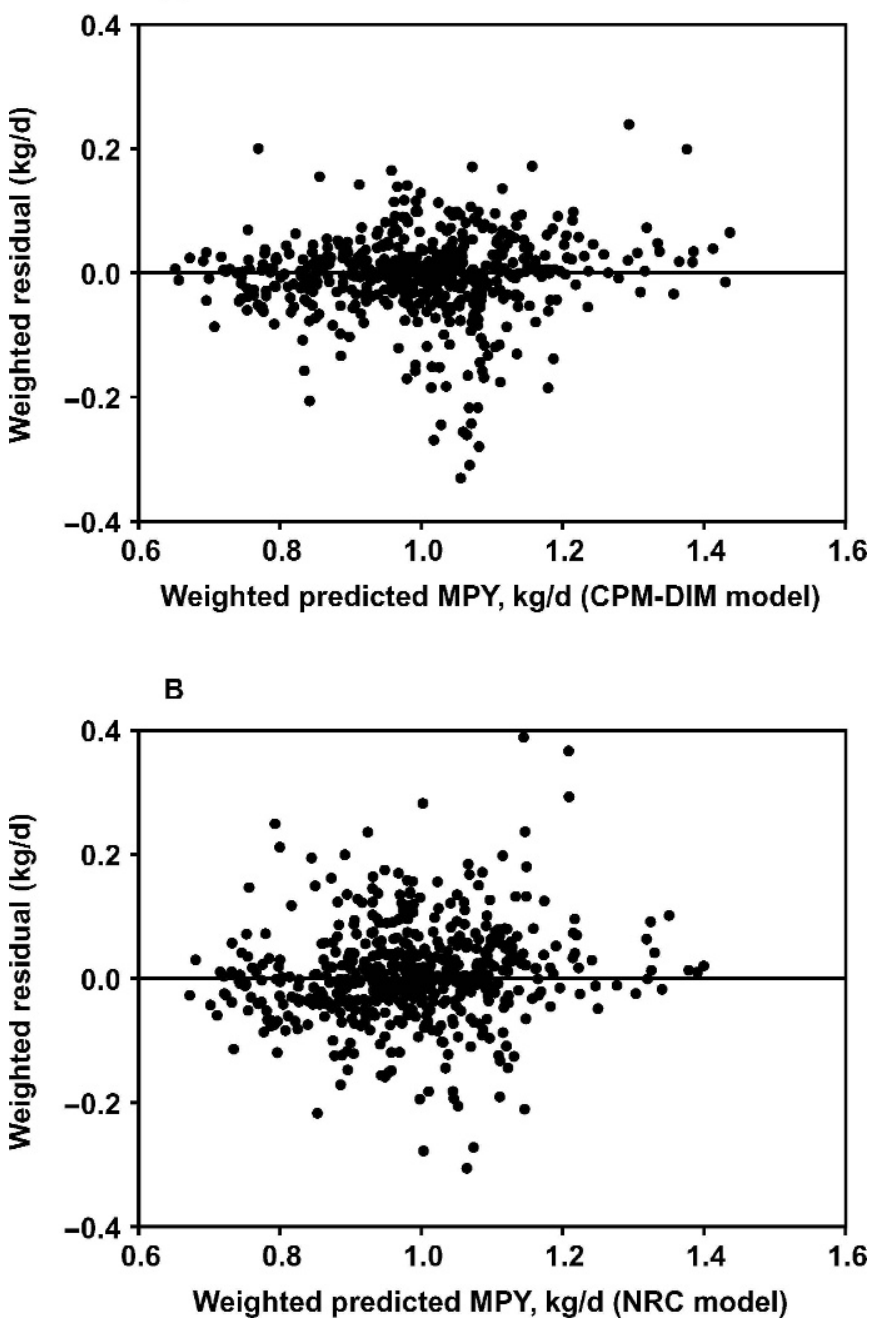

Figure 3. Weighted residuals (weighted observed - weighted predicted) vs. weighted predicted milk protein yield (MPY). A) CPMDIM model (model 8); B) NRC model (model 9). CPM = CPM Dairy, a computer program based on the Cornell Net Carbohydrate and Protein System principles; NRC = model based on NRC (2001).

smaller for the AC and DIM models, respectively, than for the DMI model. As was seen in the CPM data set, inclusion of DIM into the modeling process (model 5) produced a better fit than the AC model (model 4) with a decreased BIC value (by 163 units) and improved relationship between observed and predicted values and residual plot (Figure 2B). Ruminally undegradable protein supply and the interaction with BW showed significantly different coefficients for each DIM class. The significant random component for RUP indicated an interaction of RUP with the random effect of study. Compared with the CPM models, the best NRC model (model 5) produced a lower BIC (by 81 units compared with the CPM-DIM model, model 3).

\section{Milk Protein Yield Models}

Estimated MPY model results are shown in Table 5. Similar to the CPM-MY models, incorporation of intake variables significantly improved model BIC (by 245 and 256 units in models 7 and 8, respectively), the residual mean square error, and the residual structures (Figures $1 \mathrm{~B}$ and $3 \mathrm{~A}$ ) compared with the DMI model (model 6). Intakes of $\mathrm{NE}_{\mathrm{L}}$, fermentable $\mathrm{NDF}, \mathrm{CHO}$ fraction $\mathrm{A}$, and protein fractions $\mathrm{B} 1$ and $\mathrm{B} 2$ were significant factors in the CPM models. In addition, the models contained quadratic terms for $\mathrm{CHO}$ fraction $\mathrm{A}$ and protein fraction B2. Intake of fermentable NDF and protein fraction $\mathrm{B} 1$ and some of the quadratic terms had a negative influence in the models. Incorporation of DIM (model 8) into the CPM model (model 7) indicated moderate improvement in the model fit as measured by the 11unit decrease in BIC (and Figure 3A). Net energy of lactation and protein fraction B2 intakes and the quadratic term for protein fraction B2 intake had significantly different coefficients for the DIM1 and DIM2 classes. In both the full and reduced models, $\mathrm{CHO}$ fraction A and protein fraction B2 showed significant interactions with the random effects of study.

The NRC-MPY models were identical for both AC and DIM categories (model 9) and included intakes of NFC, RDP, RUP, BW, quadratic terms for RDP and $\mathrm{BW}$, and an RDP by BW interaction. Incorporation of intake variables instead of DMI (model 6) improved the model fit as measured by the 144-unit decrease in the BIC value and the relationship between observed and predicted values and overall residual structure (Figures $1 \mathrm{~B}$ and $3 \mathrm{~B}$ ). Intake of RDP and the quadratic terms for RDP and BW had a negative influence in the model. Intake of RDP significantly interacted with the random effects of study.

\section{DISCUSSION}

The diets included in this study encompassed a large variety of feeds (a total of 88), but the main ingredients were typical for North American dairy diets (Mowrey and Spain, 1999; Kellogg et al., 2001). Therefore, the results from this meta-analysis will be most applicable to Holstein cows fed alfalfa/corn/soybean meal-based diets.

A close relationship between DMI and milk production of dairy cows has been established (Roseler et al., 1997a; Martin and Sauvant, 2002; Voelker et al., 2002) and is confirmed in this analysis. Dry matter, however, is composed of various nutrients, some of which (individually or included in a comprehensive model) may have a stronger impact on production variables than DMI alone. Indeed, based on BIC values and a tighter 
Table 4. Estimates (regressor variables), standard errors, and significance for the fixed and random components of the final candidate models for milk yield (response in $\mathrm{kg} / \mathrm{d} ; \mathrm{n}=563$ ).

\begin{tabular}{|c|c|c|c|c|c|}
\hline Lactation stage & $\begin{array}{l}\text { Regressor } \\
\text { variables }^{1}\end{array}$ & Estimate & $\mathrm{SE}$ & $F$ value & $\begin{array}{l}\operatorname{Pr}>|t| \\
\text { or } \operatorname{Pr}>|z|^{2}\end{array}$ \\
\hline \multicolumn{6}{|c|}{ DMI model (model 1) } \\
\hline $\begin{array}{l}\left(\mathrm{BIC}^{3}=2931\right) \\
\left(\mathrm{RMSE}^{4}=2.78\right)\end{array}$ & Intercept & 8.661 & 1.3406 & 42.3 & $<0.001$ \\
\hline \multicolumn{6}{|c|}{ Model variance components } \\
\hline & Intercept & 6.645 & 2.8498 & & 0.010 \\
\hline & DMI & 0.019 & 0.0059 & & $<0.001$ \\
\hline \multicolumn{6}{|c|}{ CPM Dairy models } \\
\hline All cows (Model 2) & Intercept & 13.924 & 1.4146 & 96.0 & $<0.001$ \\
\hline$(\mathrm{BIC}=2902)$ & $\mathrm{NE}_{\mathrm{L}}$ & 0.663 & 0.0509 & 153.8 & $<0.001$ \\
\hline$(\mathrm{RMSE}=2.66)$ & FCHO & -0.829 & 0.2076 & -16.0 & $<0.001$ \\
\hline & ProtB2 & 1.131 & 0.4103 & 7.8 & 0.007 \\
\hline \multicolumn{6}{|c|}{ Model variance components } \\
\hline & Intercept & 7.864 & 1.9647 & & $<0.001$ \\
\hline & ProtB2 & 2.254 & 0.5705 & & $<0.001$ \\
\hline DIM model (Model 3) & Intercept & 15.929 & 1.3074 & 148.8 & $<0.001$ \\
\hline$(\mathrm{BIC}=2793)$ & $\mathrm{NE}_{\mathrm{L}}$ & 0.584 & 0.0460 & 161.3 & $<0.001$ \\
\hline$(\mathrm{RMSE}=2.38)$ & $\mathrm{FCHO}$ & -0.839 & 0.1866 & -20.3 & $<0.001$ \\
\hline & ProtB2 (DIM 1) & 1.803 & 0.3813 & 22.1 & $<0.001$ \\
\hline & ProtB2 (DIM 2) & -0.324 & 0.4248 & -0.6 & 0.446 \\
\hline \multicolumn{6}{|c|}{ Model variance components } \\
\hline & Intercept & 7.138 & 1.5855 & & $<0.001$ \\
\hline & ProtB2*DIM & 1.709 & 0.4150 & & $<0.001$ \\
\hline \multicolumn{6}{|c|}{ NRC 2001 models } \\
\hline All cows (Model 4) & Intercept & -16.475 & 6.6290 & -6.3 & 0.014 \\
\hline$(\mathrm{BIC}=2875)$ & $\mathrm{NE}_{\mathrm{L}}$ & 0.645 & 0.0443 & 213.2 & $<0.001$ \\
\hline$(\mathrm{RMSE}=2.52)$ & RUP & 16.297 & 5.5310 & 9.0 & 0.004 \\
\hline & BW & 0.040 & 0.0112 & 13.0 & $<0.001$ \\
\hline & RUP*BW & -0.025 & 0.0090 & -7.3 & 0.007 \\
\hline \multicolumn{6}{|c|}{ Model variance components } \\
\hline & Intercept & 6.472 & 1.8120 & & $<0.001$ \\
\hline & RUP & 5.679 & 1.2843 & & $<0.001$ \\
\hline DIM model (Model 5) & Intercept & -14.289 & 5.6118 & -6.8 & 0.012 \\
\hline$(\mathrm{BIC}=2712)$ & $\mathrm{NE}_{\mathrm{L}}$ & 0.608 & 0.0377 & 259.2 & $<0.001$ \\
\hline \multirow[t]{5}{*}{$(\mathrm{RMSE}=2.05)$} & RUP (DIM 1) & 4.982 & 4.8530 & 1.0 & 0.306 \\
\hline & RUP (DIM 2) & 29.714 & 4.9890 & 36.0 & $<0.001$ \\
\hline & BW & 0.039 & 0.0094 & 17.6 & $<0.001$ \\
\hline & RUP*BW & -0.005 & 0.0079 & -0.4 & 0.542 \\
\hline & $\mathrm{RUP} * \mathrm{BW}$ & -0.050 & 0.0081 & -38.4 & $<0.001$ \\
\hline \multicolumn{6}{|c|}{ Model variance components } \\
\hline & Intercept & 7.066 & 1.6263 & & $<0.001$ \\
\hline & RUP*DIM & 3.641 & 0.9892 & & $<0.001$ \\
\hline
\end{tabular}

\footnotetext{
${ }^{1}$ Intake and production data are in kilograms per day (megacalories per day for $\mathrm{NE}_{\mathrm{L}}$ ). $\mathrm{FCHO}=$ Fermentable carbohydrate intake; ProtB2 = protein fraction B2 intake; DIM1 = DIM $<100$ d; DIM2 = DIM $\geq 100 \mathrm{~d}$.

${ }^{2}$ For random effects.

${ }^{3} \mathrm{BIC}=$ Bayesian information criterion; lower is better.

${ }^{4} \mathrm{RMSE}=$ Root mean square error after adjusting for the random effect of experiment.
}

residual structure, MY and MPY prediction improved when intake of specific nutrients was included in the model. Therefore, this analysis suggests that MY and MPY in dairy cows can be better predicted based on intake of individual nutrients derived through the feeding programs used than on DMI alone.

With both the CPM and NRC datasets, $\mathrm{NE}_{\mathrm{L}}$ intake was the strongest regressor variable influencing MY (models 2 through 5), as suggested by the relatively larger $F$ statistic. Diets for lactating dairy cows are formulated to be highly digestible and, in most situations, DMI is strongly related to intake of total digestible nutrients, or energy $\left(\mathrm{NE}_{\mathrm{L}}\right.$, metabolizable energy) intake (Hristov et al., 2002); the Pearson correlation coefficient between $\mathrm{NE}_{\mathrm{L}}$ intake and discounted total digestible nutrients intake was $98.7 \%$ in the NRC data 
Table 5. Estimates (regressor variables), standard errors, and significance for the fixed and random components of the final candidate models for milk protein yield (response variable in $\mathrm{kg} / \mathrm{d} ; \mathrm{n}=549$ ).

\begin{tabular}{|c|c|c|c|c|c|}
\hline Lactation stage & Regressor variables $^{1}$ & Estimate & $\mathrm{SE}$ & $\mathrm{F}$ value & $\begin{array}{l}\operatorname{Pr}>|t| \\
\text { or } \operatorname{Pr}>|z|^{2}\end{array}$ \\
\hline \multicolumn{6}{|c|}{ DMI model (model 6) } \\
\hline $\begin{array}{l}\left(\mathrm{BIC}^{3}=28\right) \\
\left(\mathrm{RMSE}^{4}=5.01\right)\end{array}$ & $\begin{array}{l}\text { Intercept } \\
\text { DMI }\end{array}$ & $\begin{array}{l}0.306 \\
0.031\end{array}$ & $\begin{array}{l}0.0464 \\
0.0021\end{array}$ & $\begin{array}{r}43.6 \\
216.1\end{array}$ & $\begin{array}{l}<0.001 \\
<0.001\end{array}$ \\
\hline Model varic & $\begin{array}{l}\text { ce components } \\
\text { Intercept } \\
\text { DMI }\end{array}$ & $\begin{array}{l}0 \\
1.40 \times 10^{-5}\end{array}$ & $\overline{2.77} \times 10^{-6}$ & & $\overline{<} .001$ \\
\hline $\begin{array}{l}\text { All cows (Model 7) } \\
(\mathrm{BIC}=-217) \\
(\mathrm{RMSE}=3.06)\end{array}$ & $\begin{array}{l}\text { Intercept } \\
\text { NE }_{\mathrm{L}} \\
\text { FNDF } \\
\text { CHOA } \\
\text { ProtB1 } \\
\text { ProtB2 } \\
\text { CHOA*CHOA } \\
\text { ProtB2*ProtB2 }\end{array}$ & $\begin{array}{l}\text { airy models } \\
0.388 \\
0.001 \\
-0.038 \\
0.345 \\
-0.155 \\
0.403 \\
-0.114 \\
-0.072\end{array}$ & $\begin{array}{l}0.0635 \\
0.0007 \\
0.0083 \\
0.0680 \\
0.0156 \\
0.0387 \\
0.0259 \\
0.0110\end{array}$ & $\begin{array}{r}41.0 \\
3.2 \\
-20.2 \\
26.0 \\
-100.0 \\
108.2 \\
-19.4 \\
-42.3\end{array}$ & $\begin{array}{r}<0.001 \\
0.074 \\
<0.001 \\
<0.001 \\
<0.001 \\
<0.001 \\
<0.001 \\
<0.001\end{array}$ \\
\hline Model varic & $\begin{array}{l}\text { ce components } \\
\text { Intercept } \\
\text { CHOA } \\
\text { ProtB2 }\end{array}$ & $\begin{array}{l}0.007 \\
0.005 \\
0.003\end{array}$ & $\begin{array}{l}0.0021 \\
0.0013 \\
0.0006\end{array}$ & & $\begin{array}{l}<0.001 \\
<0.001 \\
<0.001\end{array}$ \\
\hline $\begin{array}{l}\text { DIM model }(\text { Model } 8) \\
(\mathrm{BIC}=-228) \\
(\mathrm{RMSE}=2.98)\end{array}$ & $\begin{array}{l}\text { Intercept } \\
\mathrm{NE}_{\mathrm{L}} \text { (DIM 1) } \\
\mathrm{NE}_{\mathrm{L}} \text { (DIM 2) } \\
\text { FNDF } \\
\text { CHOA } \\
\text { ProtB1 } \\
\text { ProtB2 (DIM 1) } \\
\text { ProtB2 (DIM 2) } \\
\text { CHOA*CHOA } \\
\text { ProtB2*ProtB2 (DIM 1) } \\
\text { ProtB2*ProtB2 (DIM 2) }\end{array}$ & $\begin{array}{r}0.403 \\
0.001 \\
0.011 \\
-0.028 \\
0.320 \\
-0.163 \\
0.433 \\
-0.020 \\
-0.105 \\
-0.078 \\
0.022\end{array}$ & $\begin{array}{l}0.0621 \\
0.0007 \\
0.0024 \\
0.0084 \\
0.0659 \\
0.0153 \\
0.0380 \\
0.0939 \\
0.0248 \\
0.0109 \\
0.0246\end{array}$ & $\begin{array}{c}42.3 \\
1.0 \\
23.0 \\
-10.9 \\
24.0 \\
-114.5 \\
130.0 \\
-0.04 \\
-17.6 \\
-50.4 \\
0.8\end{array}$ & $\begin{array}{r}<0.001 \\
0.333 \\
<0.001 \\
0.001 \\
<0.001 \\
<0.001 \\
<0.001 \\
0.829 \\
<0.001 \\
<0.001 \\
0.3787\end{array}$ \\
\hline Model vari & $\begin{array}{l}\text { ce components } \\
\text { Intercept } \\
\text { CHOA } \\
\text { ProtB2*DIM }\end{array}$ & $\begin{array}{l}0.007 \\
0.004 \\
0.002\end{array}$ & $\begin{array}{l}0.0019 \\
0.0011 \\
0.0005\end{array}$ & & $\begin{array}{l}<0.001 \\
<0.001 \\
<0.001\end{array}$ \\
\hline \multicolumn{6}{|c|}{ NRC 2001 model $^{5}$ (model 9) } \\
\hline $\begin{array}{l}(\mathrm{BIC}=-116) \\
(\mathrm{RMSE}=3.82)\end{array}$ & $\begin{array}{l}\text { Intercept } \\
\text { NFC } \\
\text { RDP } \\
\text { RUP } \\
\text { BW } \\
\text { RDP*RDP } \\
\text { RDP*BW } \\
\text { BW*BW }\end{array}$ & $\begin{array}{l}-0.062 \\
0.024 \\
-0.239 \\
0.098 \\
0.003 \\
-0.072 \\
0.001 \\
-3.94 \times 10^{-6}\end{array}$ & $\begin{array}{l}0.5488 \\
0.0028 \\
0.1132 \\
0.0072 \\
0.0020 \\
0.0135 \\
0.0002 \\
1.882 \times 10^{-6}\end{array}$ & $\begin{array}{c}-0.01 \\
67.2 \\
-4.4 \\
187.7 \\
1.7 \\
-29.2 \\
21.2 \\
-4.4\end{array}$ & $\begin{array}{r}0.910 \\
<0.001 \\
0.037 \\
<0.001 \\
0.200 \\
<0.001 \\
<0.001 \\
0.037\end{array}$ \\
\hline Model varic & $\begin{array}{l}\text { ce components } \\
\text { Intercept } \\
\text { RDP }\end{array}$ & $\begin{array}{l}0.001 \\
0.001\end{array}$ & $\begin{array}{l}0.0015 \\
0.0002\end{array}$ & & $\begin{array}{r}0.209 \\
<0.001\end{array}$ \\
\hline
\end{tabular}

\footnotetext{
${ }^{1}$ Intake and production data are in kilograms per day (megacalories per day for $\mathrm{NE}_{\mathrm{L}}$ ). $\mathrm{FNDF}=$ fermentable $\mathrm{NDF}$ intake; $\mathrm{CHOA}=$ carbohydrate fraction $\mathrm{A}$ intake; ProtB1 = protein fraction $\mathrm{B} 1$ intake; Prot $\mathrm{B} 2=$ protein fraction B2 intake; DIM1 = DIM $<100 \mathrm{~d}$; DIM2 = DIM $\geq 100 \mathrm{~d}$.

${ }^{2}$ For random effects.

${ }^{3} \mathrm{BIC}=$ Bayesian information criterion; lower is better.

${ }^{4} \mathrm{RMSE}=$ Root mean square error after adjusting for the random effect of experiment.

${ }^{5} \mathrm{NRC}$ models, all cows and DIM, were identical.
}

set (over all observations). The strong presence of energy intake in the MY models in this analysis reflects the critical importance of available energy for MY in the dairy cow. Milk yield was also significantly influ- enced by fermentable $\mathrm{CHO}$ and protein fraction $\mathrm{B} 2$ intakes in the CPM data set, although, based on the $F$ statistic, the relative importance of this regressor was smaller compared with $\mathrm{NE}_{\mathrm{L}}$ intake. 
The CPM-MY models (models 2 and 3 ) indicated negative coefficient for fermentable $\mathrm{CHO}$ intake. This suggests that, provided all other model regressor variables are constant, fermentable $\mathrm{CHO}$ intake would have a negative influence on the model. Although less important than $\mathrm{NE}_{\mathrm{L}}$ intake (based on the relative values of the $F$ statistic), RUP intake was a significant factor in the NRC-MY models (models 4 and 5). This is in agreement with the NRC (2001) committee report, which, based on a large data set consisting of 206 treatment means, concluded that MY increased linearly with increasing RUP concentration of the diet at a rate of $1.85 \mathrm{~kg}$ of milk for each percentage unit increase in RUP. An earlier meta-analysis by Santos et al. (1998), however, did not find a significant relationship between MY and RUP content of the diet, except for treated soybean and fish meals.

Incorporating stage of lactation (DIM1 and DIM2) in both CPM and NRC milk yield models (models 3 and 5) improved model fits. From the relative BIC values, it appeared models based on NRC-estimated intakes (models 4 and 5) provided slightly better fits for MY than models based on CPM-derived estimates (models 2 and 3 ).

Intake of $\mathrm{NE}_{\mathrm{L}}$, fermentable $\mathrm{NDF}, \mathrm{CHO}$ fraction $\mathrm{A}$, and protein fractions $\mathrm{B} 1$ and $\mathrm{B} 2$ were important in predicting MPY in the CPM models (models 7 and 8) and intake of NFC, RDP, RUP, and BW were components of the NRC model (model 9). In general, the MPY models were not very parsimonious and should be considered less reliable than the MY models. Not a single intake variable was distinctly predominant, although protein fractions B1 and B2 (CPM, models 7 and 8) and RUP (NRC, model 9) intakes had relatively the largest influence in the model ( $F$ statistic). Intakes of $\mathrm{CHO}$ fraction A and protein fraction B2 and RDP (CPM, models 7 and 8 and NRC, model 9, respectively) were significant random components in the MPY models, indicating contributions of these regressor variables to MPY variability over the studies. Moloi (1998) reported that diet-related variables, such as RDP, NDF, and NFC concentration of the diet influenced MPY in dairy cows. In the Moloi (1998) study, however, no single variable was identified as having major influence on MPY. Smoler et al. (1998) indicated generally poor prediction of milk protein concentration when diet-related variables were used in the modeling process; models included both $\mathrm{CHO}$ and protein variables. They suggested that individual $\mathrm{CHO}$ fractions might be better predictors of MPY than total CHO. Our data suggest that intake of protein fractions B1 (soluble proteins, a negative coefficient) and B2 (insoluble, available proteins) as derived through CPM and RUP (NRC) can strongly influence MPY in Holstein cows. In a similar analysis, Smoler et al. (1998) emphasized the importance of ruminally undegradable protein in predicting MPY in dairy cows. Based on a data set including 38 studies with 206 treatment means, the NRC (2001) Dairy Committee reported that MPY in dairy cows increased linearly with increasing dietary RUP concentration. Similar to the negative coefficient for fermentable $\mathrm{CHO}$ in the CPM-MY models, fermentable NDF and protein fraction B1 intakes had a negative coefficient in the CPM-MPY models (models 7 and 8). The coefficient for RDP in the NRC model (model 9) was also negative. Body weight was present in the NRCMPY model (model 9). The importance of animal variables for predicting MPY was also emphasized by Smoler et al. (1998).

\section{CONCLUSIONS}

Models based on intake of nutrients improved prediction of MY and MPY in Holstein cows compared with DMI alone. Intake of $\mathrm{NE}_{\mathrm{L}}$ was the dominant variable in MY prediction models derived from both CPM Dairy and NRC (2001) nutrient estimates. A variety of energyor protein-related parameters were also important in modeling MY. Incorporating stage of lactation in the MY models improved the model fit. Milk protein yield models based on intake of individual nutrients were generally not very parsimonious, but did improve prediction over the DMI model. These models were dominated by RUP intake and included a number of energyrelated intake variables. Incorporating stage of lactation into the CPM Dairy MPY model improved the model fit whereas it did not for the NRC model.

\section{ACKNOWLEDGMENTS}

This study was partially supported by funds from the Idaho Agricultural Experiment Station. The authors would like to thank K. A. Hristova, T. Hubert, R. Manzo, K. L. Grandeen, and J. K. Ropp for assistance with collection of the initial data used in this study.

\section{REFERENCES}

DePeters, E. J., and J. P. Cant. 1992. Nutritional factors influencing the nitrogen composition of bovine milk: A review. J. Dairy Sci. 75:2043-2070.

Firkins, J. L., M. L. Eastridge, N. R. St-Pierre, and S. M. Noftsger. 2001. Effects of grain variability and processing on starch utilization by lactating dairy cattle. J. Anim. Sci. 79(E. Suppl.):E218E238.

Fuentes-Pila, J., M. Ibañez, J. M. De Miguel, and D. K. Beede. 2003. Predicting average feed intake of lactating Holstein cows fed totally mixed rations. J. Dairy Sci. 86:309-323.

Hristov, A. N., K. A. Hristova, and W. J. Price. 2000. Relationship between dry matter intake, body weight, and milk yield in dairy cows: A summary of published data. J. Dairy Sci. 83(Suppl. 1):260. 
Hristov, A. N., W. J. Price, and B. Shafii. 2002. An overview of dietary factors influencing dry matter intake and milk and milk protein yields in dairy cows. Pages 147-165 in Proc. Pacific Northwest Animal Nutrition Conference, Vancouver, BC, Canada. C R Press, Portland, OR.

Hristov, A. N., W. J. Price, and B. Shafii. 2004. A meta-analysis examining the relationship among dietary factors, dry matter intake, and milk yield and milk protein yield in dairy cows. J. Dairy Sci. 87:2184-2196.

Jarrige, R. 1989. Ruminant Nutrition. Recommended allowances and feed tables. Institut National de la Recherche Agronomique. Libbey, Eurotext, Paris, France.

Kellogg, D. W., J. A. Pennington, Z. B. Johnson, and R. Panivivat. 2001. Survey of management practices used for the highest producing DHI herds in the United States. J. Dairy Sci. 84(E. Suppl.):E120-E127.

Kertz, A. F., L. F. Reutzel, and O. M. Thomson. 1991. Dry matter intake from parturition to midlactation. J. Dairy Sci. 74:2290 2295.

Martin, O., and D. Sauvant. 2002. Meta-analysis of input/output kinetics in lactating dairy cows. J. Dairy Sci. 85:3363-3381.

Moloi, I. P. 1998. Meta-analysis of nutritional factors that affect milk protein yield. M.S. Thesis. University of Idaho, Moscow.

Moore, T. L., and I. L. Mao. 1990. Prediction of total intake of dry matter and net energy in a lactation. J. Dairy Sci. 73:1255-1262.

Mowrey, A., and J. N. Spain. 1999. Results of a nationwide survey to determine feedstuffs fed to lactating dairy cows. J. Dairy Sci. 82:445-451.

NRC. 2001. Nutrient Requirements of Dairy Cattle. 7th rev. ed. National Academy Press, Washington, DC.
Oldick, B. S., J. L. Firkins, and N. R. St-Pierre. 1999. Estimation of microbial nitrogen flow to the duodenum of cattle based on dry matter intake and diet composition. J. Dairy Sci. 82:1497-1511.

Rook, A. J., J. D. Sutton, and J. France. 1992. Prediction of the yield of milk constituents in dairy cows offered silage ad libitum and concentrate at a flat rate. Anim. Prod. 54:313-322.

Roseler, D. K., D. G. Fox, A. N. Pell, and L. E. Chase. 1997a. Evaluation of alternative equations for prediction of intake for Holstein dairy cows. J. Dairy Sci. 80:864-877.

Roseler, D. K., D. G. Fox, L. E. Chase, A. N. Pell, and W. C. Sone. 1997b. Development and evaluation of equations for prediction of feed intake for lactating Holstein dairy cows. J. Dairy Sci. 80:878-893.

Santos, F. A. P., J. E. P. Santos, C. B. Theurer, and J. T. Huber. 1998. Effects of rumen-undegradable protein on dairy cow performance: A 12-year literature review. J. Dairy Sci. 81:3182-3213.

SAS Institute. 2004. SAS OnlineDoc 9.1.2. SAS Institute, Inc., Cary, NC.

Smoler, E., A. J. Rook, J. D. Sutton, and D. E. Beever. 1998. Prediction of milk protein concentration from elements of the metabolism protein system. J. Dairy Sci. 81:1619-1623.

Sniffen, C. J., J. D. O'Connor, P. J. Van Soest, D. G. Fox, and J. B. Russell. 1992. A net carbohydrate and protein system for evaluating cattle diets: II. Carbohydrate and protein availability. J. Anim. Sci. 70:3562-3577.

St-Pierre, N. R. 2001. Integrating quantitative findings from multiple studies using mixed model methodology. J. Dairy Sci. 84:741-755.

St-Pierre, N. R. 2003. Reassessment of biases in predicted nitrogen flows to the duodenum by NRC 2001. J. Dairy Sci. 86:344-350.

Voelker, J. A., G. M. Burato, and M. S. Allen. 2002. Effects of pretrial milk yield on responses of feed intake, digestion, and production to dietary forage concentration. J. Dairy Sci. 85:2650-2661. 